Kemandirian Anak Panti Asuhan

Ervina Rianti ${ }^{1^{*}}$, Ifdil ${ }^{2}$

${ }^{12}$ Universitas Negeri Padang, Sumatera Barat, Indonesia.

Correspondence regarding this article should be addressed to: Author address e-mail: ervinarianti1@gmail.com

\begin{abstract}
Kemandirian merupakan aspek penting yang harus dimiliki oleh seorang anak, apalagi untuk anak yang tidak lagi tinggal bersama orangtua. Kemandirian secara sederhana artinya tidak terlaliu bergantung kepada orang lain. Dalam beberapa hal tertentu anak memang sebaiknya dilatih untuk hidup mandiri agar ketika dewasa, mereka tidak merasa kesulitan jika harus tinggal jauh dari orang tua, dan sedini mungkin kemandirian itu harus dilatihkan kepada anak, terutama untuk anak yang tidak tinggal dengan orangtua, seperti anak panti asuhan.Panti Asuhan merupakan salah satu lembaga sosial yang sengaja didirikan oleh pemerintah ataupun kalangan swasta dengan tujuan menampung anak - anak terlantar, yang keluarganya tidak ada atau tidak mampu membiayai kehidupannya. Anak-anak yang tinggal di panti asuhan pada umumnya lebih mandiri bila dibandingkan dengan anak - anak yang tinggal dengan orangtua. Hal ini disebabkan salah satunya oleh ketersediaan materi yang dimiliki oleh orangtua dalam pemenuhan kebutuhan anak yang tinggal dengan orangtua, sementara di panti asuhan, anak - anak harus menerima segala keterbatasan baik materi ataupun hal lainnya.
\end{abstract}

Keywords: Kemandirian, Panti Asuhan

Article History: Received on 01/07/2019; Revised on 05/08/2019; Accepted on 17/08/2019; Published Online: 31/08/2019.

This is an open access article distributed under the Creative Commons Attribution License, which permits unrestricted use, distribution, and reproduction in any medium, provided the original work is properly cited. (2019 by author.

PENDAHULUAN

Pada hakikatnya, belajar menjadi anak yang mandiri bukanlah hal yang mudah, apalagi tanpa dukungan langsung dari orangtua. Namun, bagi anak yang tidak tinggal dengan orangtua, kemandirian merupakan suatu keharusan yang harus mereka miliki, seperti hal nya anak-anak yang tinggal di panti asuhan. Tuntutan keadaan membuat mereka mau tak mau harus bisa menjadi anak-anak yang mandiri, yang harus bisa mengurus diri sendiri dan sebisa mungkin tidak terlalu bergantung kepada orang lain. Ketiadaan orangtua kandung di panti asuhan membuat mereka tidak bisa bermanjamanja, seperti anak-anak kebanyakan, sebab semakin rendah tingkat ketergantungan mereka terhadap orang lain, akan membuat kemandirian mereka semakin tinggi. 


\section{Kemandirian Anak Panti Asuhan}

Kemandirian untuk anak-anak yang tinggal di panti asuhan juga bukan hal yang tabu, sebab mereka sudah terbiasa dengan ketiadaan orangtua yang biasanya memfasilitasi segala kebutuhan. Namun, jika di panti asuhan, mereka selalu diajarkan untuk mempersiapkan segala kebutuhan tersebut seorang diri, seperti keperluan sekolah, dan keperluan lain yang mereka butuhkan. Tak hanya itu, aktivitas mencuci pakaian, menyetrika pakaian juga mereka lakukan secara mandiri. Hal ini bertujuan agar mereka tidak terlalu canggung untuk melanjutkan kehidupan, walalupun dengan ketiadaan orangtua.

Individu sejatinya diharuskan untuk dapat hidup secara mandiri dan dapat membantu orang lain. Hidup mandiri dan tidak bergantung kepada oan lain merupaka suatu hal yang harus da didalam dirindividu. Setiap orang yang hdup membuuhkan oang lain akan tetapi bukan berarti harus memnusahkan orang lain. Mandiri yang dimaksdu disini adaah mampu untu memandirikan diri dalam segaa hal.

Panti asuhan tidak semata-mata, hanya menampung anak-anak yang terlantar, ataupun anak-anak yang ditinggal oleh orantuanya, melainkan juga sebagai lembaga yang dapat mendidik anak-anak nya menjadi generasi terdidik yang berakhlak mulia, yang dapat menjadi anak yang memiliki keterampilan, sehingga dapat menjadi generasi penerus bangsa yang berkarakter cerdas, serta mandiri.

\section{PEMBAHASAN}

\section{Kemandirian}

Secara sederhana, mandiri berarti tidak bergantung kepada orang lain dalam berbagai aspek kehidupan. Sedangkan dari arti kata nya, mandiri berarti berdiri sendiri. Sementara itu, (Natasha, 2016) mengatakan bahwa kemandirian adalah perilaku yang menunjukkan kedewasaan yang mampu mengembangkan diri, bertanggung jawab, tampil sebagai totalitas pribadi yang mantap, menyadari apa yang dilakukan dan alasan melakukannya serta mampu menunjukan kontrol diri terhadap perilakunya.

Hal lain terkait kemandirian juga disampaikan oleh (Utari Ridhayanti, 2018) yaitu keadaan seseorang yang dapat menentukan diri sendiri dimana dapat dinyatakan dalam tindakan atau perilaku seseorang yang dapat dinilai. Selanjutnnya, menurut (Lukman, 2000) dalam sikap kemandirian terkandung beberapa hal: 1) kemandirian merupakan bagian dari kepribadian, 2) dapat menentukan diri serta arah tindakannya, 3) adanya kecenderungan untuk memenuhi kebutuhannya sendiri, dan 4) dalam kerangka dukungan sosial.

Dari beberapa defenisi diatas, maka dapat disimpulkan bahwa kemandirian merupakan suatu keadaan yang memungkinkan individu dapat melakukan berbagai aktivitas tanpa bergantung pada orang lain, serta dapat mempertanggungjawabkan apa yang telah ia kerjakan.

Menurut (Muhammad Ali, 2014) kemandirian memiliki ciri - ciri sebagai berikut :

a. Kebebasan, individu bisa memutuskan gaya hidup yang disenanginya dan mengambil keputusan tanpa bergantung pada orang lain. 
b. Tanggung jawab, individu bersedia menerima resiko dari apa yang telah ia putuskan.

c. Memiliki pertimbangan, individu mampu memikirkan secara rasional setiap masalah dan situasi yang sedang ia alami.

d. Merasa aman ketika berbeda dengan orang lain, dalam artian berani mempertahankan pendapatnya sendiri.

e. Kreativitas, individu mampu memnghasilkan sesuatu yang baru, yang tidak melulu

f. harus berpatokan kepada hasil kerja orang lain.

Adapun faktor - faktor yang mempengaruhi kemandirian menurut Hurlcok (dalam Lukman, 2000), antara lain :

a. Keluarga, misalnya perlakuan ibu terhadap anak.

a. Sekolah, misalnya perlakukan guru dan teman sebaya.

b. Media, komunikasi massa, misalnya majalah, koran, televisi dan sebagainya.

c. Agama, misalnya sikap terhadap agama yang kuat.

d. Pekerjaan atau tugas yang menuntut sikap pribadi teretentu.

Selajutnya, menurut Soetjiningsih (dalam Utari Ridhayanti, 2018) faktor - faktor yang dapat mempengaruhi kemandirian anak, adalah sebagai berikut :

a. Faktor internal, diantaranya : emosi dan intelektual.

b. Faktor eksternal, diantaranya: lingkungan, karakteristik sosial, stimulasi, komunikasi antar pribadi, cinta dan kasih sayang, kualitas interaksi anak dan orangtua sebagai pengasuh, pendidikan dari orangtua.

Selanjutnya, Hurlock (dalam (Muhammad Ali, 2014) mengatakan bahwa banyak remaja ingin mandiri, namun mereka juga ingin dan butuh rasa aman yang diperolehnya dari ketergantungan emosi kepada orangtua atau orang dewasa lain. Remaja masih memerlukan bimbingan dan dukungan orangtua dalam memutuskan rencana masa depan dan hal-hal yang penting dalam kehidupannya. Remaja juga biasanya masih membutuhkan bantua dalam segi ekonomi dari orangtua. Hal-hal tersebut membuat remaja tidak dapat bebas sepenuhya dari orangtua. Ia masih dituntut untuk tetap mentaati aturan dan permintaan orang tua. Keinginan remaja untuk mengatur hidupnya sendiri berbenturan dengan rasa tanggung jawab orangtua untuk memperhatikan perkembangan anak-anaknya. Konflik yang trerjadi merupakan hal yang biasa mewarnai kehidupan ketika anak masih remaja.

\section{Panti Asuhan}

Panti adalah rumah, tempat (kediaman), sedangkan asuhan adalah rumah tempat memelihara dan merawat anak yatim/yatim piatu dan sebagainya. Panti asuhan adalah tempat untuk mengasuh anak-anak yatim, piatu, atau yatim-piatu, bahkan anak-anak terlantar untuk dibina menjadi anak yang mandiri, bertanggung jawab, serta patuh dan berguna bagi masyarakat, nusa dan bangsa. Secara umum dalam Kepmensos No.50/HUK/2004 dijelaskan bahwa Panti Sosial Asuhan Anak adalah: "Panti sosial yang mempunyai tugas memegang fungsi yang harus dijalankan 


\section{Kemandirian Anak Panti Asuhan}

dalam penyelenggaraannya, fungsi - fungsi tersebut terwujud dalam pelayanan bagi anak yatim, piatu, yatim piatu, anak yang kurang mampu, dan terlantar agar potensi dan kapasitas belajarnya pulih kembali dan dapat berkembang secara wajar."

Menurut (Gharnish Tiara Resty, 2015) panti asuhan adalah suatu tempat yang sengaja diberikan untuk membentuk kepribadian dan perkembangan setra pertumbuhan bagi anak-anak yang memiliki permasalahan dengan keluarganya, baik yang masih memiliki keluarga atau sudah tidak memiliki keluarga.

Sedangkan, menurut (Yahyasulthoni, 2013) panti asuhan merupakan salah satu wahana untuk mengatasi kendala-kendala sosial yang sedang berkembang, seperti, kemiskinan pendidikan, anak-anak terlantar, korban bencana alam, dan lain sebagainya.Dikatakan salah satu wahana untuk menangani masalah-masalah sosial, karena pemerintah dalam hal ini belum mampu menangani masalah masalah sosial secara keseluruhan lebih-lebih pada krisis dan reformasi ini

Dari beberapa penjelasan diatas, maka dapat disimpulkan bahwa panti asuhan adalah salah satu jenis lembaga sosial yang berupaya menampung anak yatim, piatu, yatim piatu, ataupun anak yang ditinggalkan atau diterlantarkan oleh orangtuanya, dengan tujuan agar mereka memperoleh kehidupan yang layak.

Adapun karakteristik anak panti asuhan menurut (Annajah \& Falah, 2016) antara lain :

1. Anak yatim

2. Anak piatu

3. Anak yatim piatu

4. Anak terlantar

5. Anak yang sedari bayi dititipkan di panti asuhan

6. Anak yang sengaja dititipkan di panti asuhan dengan beberapa alasan (perekonomian, keadaan hubungan keluarga, pendidikan).

Anak panti asuhan yang tidak diasuh langsung oleh keluarganya, tentu saja memiliki beragam permasalahan, sebagaimana yang dikemukakan oleh (Rahmah \& Ilyas, 2014) sebagai berikut :

1. Masalah penyesuaian diri dengan lingkungan teman sebaya

2. Masalah penyesuaian diri dengan lingkungan pengasuh

3. Masalah penyesuaian diri dengan masyarakat di sekitar panti

4. Masalah penyesuaian diri dengan lingkungan sekolah

\section{Kemandirian Anak Panti Asuhan}

Segala kegiatan yang diprogramkan oleh setiap panti asuhan diharapkan dapat menjadikan anak sebagai individu yang mandiri, yang dalam kehidupannya tidak akan selalu bergantung kepada orang lain, sebab anak yang tinggal di panti asuhan memang di didik untuk hidup mandiri, jika dibandingkan dengan anak - anak yang tinggal dengan orantuanya. Oleh seb aitu, anak panti asuhan sebisa mungkin diarahkan melakukan segala sesuatunya secara mandiri. 
Di panti asuhan anakanak di ajarkan untuk dapat hidup mandiri dan dapat megerjakan sendiri tanpa menyusahkan orang lain. Di dalam panti asuhan anak-anak bkerja secara suka rela dan tidak boleh mandiri. Banggun pagi tidak ada yang dibangunn dan bagn sendiri dan ibadah nomor 1 ,

Penananaman nilai kemandirian di panti asuhan dilakukan dengan cara membangun kesadaran anak asuh bahwa panti asuhan merupakan miliki mereka sendiri dan segala pemenuhan kebutuhan menjadi tanggung jawab mereka sendiri, panti asuhan hanya memfasilitasi. Anak asuh mencuci pakaian sendiri, menyetrika baju sendiri, ketika mereka membutuhkan uang, panti asuhan memfasilitasi kebutuhan tersebut. Adanya peraturan dan tata tertib serta jadwal keseharian membuat anak menjadi disiplin sehingga tidak bersikap kekanak-kanakan yang terus mengandalkan bantuan orang lain. Mereka sudah mengerti apa yang harus mereka kerjakan untuk kehidupan mereka di panti tanpa harus meminta bantuan orang lain. Peraturan yang ada dijalankan dengan tertib dan tegas oleh pengelola panti asuhan (Yahyasulthoni, 2013).

\section{KESIMPULAN}

kemandirian adalah perilaku yang menunjukkan kedewasaan yang mampu mengembangkan diri, bertanggung jawab, tampil sebagai totalitas pribadi yang mantap, menyadari apa yang dilakukan dan alasan melakukannya serta mampu menunjukan kontrol diri terhadap perilakunya. panti asuhan adalah salah satu jenis lembaga sosial yang berupaya menampung anak yatim, piatu, yatim piatu, ataupun anak yang ditinggalkan atau diterlantarkan oleh orangtuanya, dengan tujuan agar mereka memperoleh kehidupan yang layak.

\section{REFERENCES}

Annajah, U., \& Falah, N. (2016). Pengaruh Lingkungan Sosial Terhadap Motivasi Berprestasi Anak Panti Asuhan Nurul Haq Yogyakarta, 13(1), 102-115.

Gharnish Tiara Resty. (2015). Pengaruh Penerimaan Diri Terhadap Harga Diri Remaja Di Panti Asuhan Yatimputri Aisyiyah Yogyakarta, (November).

Lukman, M. (2000). Kemandirian Anak Asuh Di Panti Asuhan Yatim Islam Ditinjau Dari Konsep Diri Dan Kompetensi Interpersonal, 5(10).

Muhammad Ali, M. A. (2014). Psikologi Remaja (Perkembangan Peserta Didik). Jakarta: Bumi Aksara.

Natasha, D. R. (2016). Peran Pendidikan Panti Asuhan Dalam Mengembangkan Kemandirian Anak (Studi Kasus: Panti Asuhan Aisyiyah Semarang) Skripsi.

Rahmah, S., \& Ilyas, A. (2014). Masalah-Masalah Yang Dialami Anak Panti Asuhan Dalam Penyesuaian Diri Dengan Lingkungan, 3(3).

Utari Ridhayanti. (2018). Peran Pengasuh Dalam Pembinaan Kemandirian Anak 
Melalui Pendekatan Ajaran Islam.

Yahyasulthoni. (2013). Strategi Pembentukan Karakter Anak Di Panti Asuhan Muhammadiyah Wiyung Surabaya. Kajian Moral Dan Kewarganegaraan, 1(1), 272287. 